DOI: $10.30525 / 978-9934-588-61-7-7$

\author{
Dr. Pawel Dziekański \\ Jan Kochanowski University in Kielce \\ ORCID: https://orcid.org/0000-0003-4065-0043, \\ e-mail:pdziekan@interia.eu \\ Dr. hab. prof. Andrzej Pawlik \\ Jan Kochanowski University in Kielce \\ ORCID: https://orcid.org/0000-0003-2319-6707 \\ e-mail:andrzejp1@vp.pl
}

\title{
FINANCIAL SITUATION OF CITIES WITH POVIAT RIGHTS IN EASTERN POLAND VOIVODSHIPS IN 2009-2017
}

\section{Summary}

The financial situation of cities with poviat rights is the state of finances within a specified period of time. Its level is demonstrated by, among others, ability to achieve budget balance and increase assets. The financial situation is strongly correlated with the measure of development potential, own revenues as well as revenues from PIT and CIT as well as transfer revenues. The financial situation is also influenced by investment expenditure and expenditure on education. The aim of the article is to assess the financial situation of cities with poviat rights in Eastern Poland using the synthetic measure. The conducted analysis concerns the comparison of the situation in 2009 and 2017. The information basis for the research is the data taken from the Central Statistical Office, BDL.

\section{Introduction}

Cities with poviat rights operate in a very dynamic and complex environment constituting places gathering economic activity. They perform functions assigned not only to poviats but also to communes (Kozera, 2016, pp. 145-166) and are characterized by independence in making decisions. Their activities are directed towards endogenous resources, i.e. financial, human, material and information. In the operation of local government units, which are cities with poviat rights, the financial situation, which affects the economic situation of the local government, is of special importance (Dworakowska, 2013, pp. 31-39). The multidimensionality of their functioning is demonstrated by the directions of using interdependent and related economic, social, infrastructural and natural factors (Dziekański, Wiraszka, 2018).

Actions of cities with poviat rights (as well as communes, poviats, voivodships) depend on the financial situation. Financial resources are the basis for the operation of the unit and a condition for the implementation of its 
statutory tasks (Borodo, 2007, p. 200). The financial situation is correlated with the level of local development. Development is a process of quantitative and qualitative changes within a given entity. It refers to the standard of living of residents and the activities of business entities (Sobczyk, 2010, pp. 125-136), and also translates into disproportions in the scope of the ability to meet local needs and the quality of implementation of public tasks. The aim of the article is to assess the financial situation of cities with poviat rights in Eastern Poland using the synthetic measure. The conducted analysis concerns the comparison of the situation in 2009 and 2017. The information basis for the research is the data taken from the Central Statistical Office, BDL (Local Data Bank).

\section{Part 1. Methodology and materials used}

Cities with poviat rights of underdeveloped voivodships of Eastern Poland are the object of interest of the authors. S. Korenik points to the process of thickening economic and social activity around active economic centers and the disappearance of this activity as they move away from them. He also emphasizes that disparities in the level of development are the natural phenomenon and that it is more important to support the progress of individual regions at their own pace adapted to their capabilities than to level the differences between regions at all costs ${ }^{1}$.

The variables used to analyze the financial situation of cities with poviat rights in Eastern Poland voivodships are presented in Table 1. Due to the subject of the analysis, the basic criterion for selecting features for further research has been meeting the significance requirement (Pawlik, 2014, p. 94).

Table 1

\section{List of variables describing the financial situation of cities with poviat rights in Eastern Poland voivodships}

\begin{tabular}{|l|c|}
\hline \multicolumn{1}{|c|}{ Variable } & S/D $^{\mathbf{a}}$ \\
\hline Share of own income in total income (financial independence indicator) & $\mathrm{S}$ \\
\hline Share of tax revenues (PIT and CIT) in total revenues (index of fiscal wealth) & $\mathrm{S}$ \\
\hline Operating surplus per capita & $\mathrm{S}$ \\
\hline $\begin{array}{l}\text { Share of transfer income in total revenue (indicator of financial interference } \\
\text { by the state) }\end{array}$ & $\mathrm{D}$ \\
\hline Share of property expenditure in total expenditure (investment attractiveness ratio) & $\mathrm{S}$ \\
\hline Expenses for debt service per capita & $\mathrm{D}$ \\
\hline Expenses for housing economy per capita & $\mathrm{S}$ \\
\hline Expenses for education and upbringing per capita & $\mathrm{S}$ \\
\hline Expenses for healthcare per capita & $\mathrm{S}$ \\
\hline Expenses for public safety and fire protection per capita & $\mathrm{S}$ \\
\hline Self-financing index & $\mathrm{S}$ \\
\hline
\end{tabular}

Source: author's own compilation

${ }^{1}$ S. Korenik, 2011, Region ekonomiczny w nowych realiach spoteczno-gospodarczych, Warszawa, CeDeWu, s. 194. 
The analysis was made using two synthetic measures and was carried out in successive stages (Dziekański, 2018a, 2018b, 2018c). The diagnostic variables describing the studied phenomenon were selected, determining also whether the given variable was a stimulant or a destimulant. From the set of variables, using a coefficient of variation, those characterized by low variability and those with high correlation of variables according to the inverted matrix method were removed (Malina, 2004, pp. 96-97).

In the next stage, the destimulant was replaced with a stimulant according to the formula (Kolenda, 2003):

$$
x_{i j}=\frac{1}{x_{i j}}
$$

The selected variables were subjected to the procedure of zero unitarization using the following formula:

$$
z_{i j}=\frac{\mathrm{x}_{i j}-\min _{i} \mathrm{x}_{i j}}{\max _{i} \mathrm{x}_{i j}-\min _{i} x_{i j}}, \text { where } x_{i} \in S
$$

where: S-stimulant, $i=1,2 \ldots n ; j=1,2 \ldots n$, xij - means the value of the $j$ th feature for the examined unit, max - the maximum value of the $j$-th feature, min - the minimum value of the j-t feature (Wysocki, 1996; Młodak, 2006; Wysocki, Lira 2005).

As a part of the adopted method, a synthetic measure of financial situation was determined separately for each city with poviat rights based on the TOPSIS method, taking into account the distance between the unit and the pattern $(=1)$ and antipattern $(=0)$, according to the following formulas:

$$
\begin{aligned}
& d_{i}^{+}=\sqrt{\frac{1}{n} \sum_{j=1}^{m}\left(z_{i j}-z_{j}^{+}\right)^{2}} \\
& d_{i}^{-}=\sqrt{\frac{1}{n} \sum_{j=1}^{m}\left(z_{i j}-z_{j}^{-}\right)^{2}}
\end{aligned}
$$

where $\mathrm{n}$ - is the number of variables that make up the pattern or antipattern, $\mathrm{z}_{i j}$ - means the unified value of the $\mathrm{j}$-th feature for the unit being tested, $z_{j}^{+}, z_{j}^{-}$- means the pattern or antipattern.

Then the TOPSIS measure was determined for individual objects based on the formula:

$$
q_{i}=\frac{d_{i}^{-}}{d_{i}^{-}+d_{i}^{+}}, \text {gdzie } 0 \leq q_{i} \leq 1, i=1,2, \ldots, n ;
$$

with: $q i \in[0 ; 1]$; $\max i\{q i\}$ - the best object; $\min i\{q i\}$ - the worst object, $d_{i}^{-}$-means the distance of the object from the anti-pattern (from 0 ), $d_{i}^{+}-$ means the distance of the object from the pattern (from 1). The higher value of the measure indicates a better situation of the individual in the studied area (Wójcik-Leń, et al., 2019; Behzadian, et al., 2012; Zalewski, 2012; Hwang, Yoon 1981). 
The second synthetic measure was determined using the reference-free method, consisting of averaging normalized values of simple features, according to the formula:

$$
S_{i}=\frac{1}{p} \sum_{j=1}^{p} z_{i j} ; i=1,2, \ldots, p,
$$

where: $\mathrm{Si}$ - synthetic measure in the examined period, zij - features of the structure of the synthetic indicator, $\mathrm{p}$ - number of features. The indicator takes the value from the range $[0,1]$. A value closer to unity means that the object is characterized by a high level of the analyzed phenomenon, whereas when the values are closer to 0 , the object is less developed in the examined respect (Dziekański, 2018a, 2018b, 2018c).

In the last stage of analyses, in order to interpret the obtained measures, the division into quartile groups was used, where the size of the indicator in the first group means a better unit and weaker units in subsequent groups. The mutual consistency of the obtained results was also verified based on the correlation coefficient and a scatter chart of synthetic measure was presented (Dziekański, Wyszkowski, 2018; Zeliaś, Malina, 1997; Nowak 1990).

\section{Part 2. Diversification of the financial situation of cities with poviat rights in Eastern Poland voivodships}

Cities with poviat rights combine the features and tasks of the commune and poviat. They carry out the tasks of the commune and poviat (Kotlińska, 2012, p. 151; Dworakowska 2013, p. 31). They have legal personality and create their own financial policy under existing law, which is related to their financial independence (Wyszkowska, Wyszkowski, 2015, p. 132). By implementing tasks in the social and infrastructural sphere, they affect the standard of everyday life of the population and the socio-economic development of the region. As at January 1, 2018, 66 cities in Poland had poviat status, and in eastern voivodships there were 14 cities with poviat status. Cities with poviat rights are the driving force of the dynamics of the local and regional economy.

The importance of cities with poviat rights in the implementation of public tasks was highlighted, among others, by Dylewski and Stasik (2012, pp. 49-60), and Dolewka (2014, pp. 31-41). The scope of financial resources at the disposal of cities with poviat rights is inadequate in relation to the increasingly numerous needs related to the organization and implementation of ongoing and development-oriented tasks (Pawlik, 2018).

Research conducted by P. Churski (2013) and co-authors as well as M. Stanna $(2013,2015)$ and P. Dziekański (2018) indicate that finance is an important development factor. Focusing on the issues of income and expenditure of municipal governments, these authors emphasize the importance of finance from the point of view of the potential financing of 
development-oriented tasks. Unfavorable changes in the demographic and social situation (e.g. aging of the society) may affect the income situation, limit their financial independence and, as a consequence, contribute to limiting their development. Entities with adequate income potential and level of financial independence can afford investment activities that favor the development of cities with poviat rights (Kotlińska, 2012, p. 152).

Douglas and Gaddie (2002), Benreke (1996) relate the financial situation to the ability to timely fulfill financial obligations by local authorities (towards lenders, employees, consumers and others) and to ensure continuity in providing services to the local community. Lin, Raman (1998), on the other hand, describe it as a probability as to maintaining services at the current level with an appropriate level of taxes. The financial situation of the commune is the state of its finances within a specified period of time. Its level is demonstrated by, among others, ability to achieve budget balance and increase assets, to analyze the financial situation, among others, variables such as: commune income level, financial independence of the entity, volume of investment expenditure, ability to obtain external financial resources, financial result achieved by the commune (Ossowska, Zieminska, 2010). The financial situation of cities with poviat rights may be determined by dependent factors: the area, in which the unit operates (e.g., location and size of local government units), available resources and natural assets, investment attractiveness as well as factors independent of them, e.g., economic fluctuations in the country and in the world, state public finance, the scope of income and expenditure authority of local government units (Dziekański, 2013, 2014).

Financial potential affects the proper functioning and development of local government units. The implementation of the tasks of cities with poviat rights is closely related to finance. Financial resources are an element necessary for the effective implementation of the objectives of individuals. Feedback occurs between socio-economic and financial variables (Dennis, 2004; Motek, 2006; Satoła, 2015; Standar, 2017). On the one hand, good financial standing is the goal of the individual's operation, and on the other, the result of previous decisions and related development opportunities.

In 2017, the financial standing measure (TOPSIS) ranged from 0.28 Chełm - the weakest unit to 0.48 Rzeszów - the best unit, while, in 2009, from 0.29 Chełm and Przemyśl to 0.51 Olsztyn. The range of values adopted by the measure of financial position was lower in 2017 (range 0.20 ) than in 2009 (range 0.22). The synthetic Si measure, on the other hand, took values in 2017 from 0.25 - Chełm to 0.48 - Rzeszów, and in 2009 from 0.25 Chełm to 0.51 - Olsztyn. The range of Si measures in 2017 was 0.23 and was lower than in 2009 when it was 0.26 . This indicates a similar range of unit differentiation, see Table 2.

Figure 1 presents the level of diversification of the financial situation of cities with poviat rights in Eastern Poland in 2009 and 2017 prepared on the 
basis of synthetic measures. Units extremely far out in this regard are: Rzeszów and Białystok as well as Zamość, Przemyśl and Chełm.

The analysis of the diversity of the measure of the synthetic financial situation indicates that, in 2017, compared to 2009, the degree of differentiation was smaller. This is evidenced by the values of the standard deviation for the TOPSIS measure: 0.08-0.06 and for the Si measure: 0.090.06 and the classic coefficient of variation respectively: $0.19-0.14$ and $0.23-$ 0.18 as well as the range for TOPSIS: $0.22-0.20$ and for $\mathrm{Si}: 0.26-0.24$ see Table 3.

Table 2

\section{Quartile groups of synthetic measures of the financial situation of cities} with poviat rights in Eastern Poland voivodships in 2009 and 2017

\begin{tabular}{|c|c|c|c|c|}
\hline \multirow[b]{2}{*}{ Gr. } & \multicolumn{2}{|c|}{ TOPSIS financial situation } & \multicolumn{2}{|c|}{ Si financial situation } \\
\hline & 2009 & 2017 & 2009 & 2017 \\
\hline I & $\begin{array}{l}\text { Olsztyn } 0.51 \\
\text { Rzeszów } 0.49 \\
\text { Lublin } 0.49 \\
\text { Kielce } 0.49 \\
\text { Elbląg } 0.49\end{array}$ & $\begin{array}{ll}\text { Rzeszów } & 0.48 \\
\text { Bialystok } & 0.46 \\
\text { Krosno } & 0.41 \\
\text { Lublin } & 0.39 \\
\text { Łomża } & 0.39 \\
\text { Kielce } & 0.39 \\
\text { Elbląg } & 0.39 \\
\text { Olsztyn } & 0.39\end{array}$ & $\begin{array}{ll}\text { Olsztyn } & 0.51 \\
\text { Kielce } 0.49 \\
\text { Rzeszów } 0.48 \\
\text { Białystok } \quad 0.48\end{array}$ & 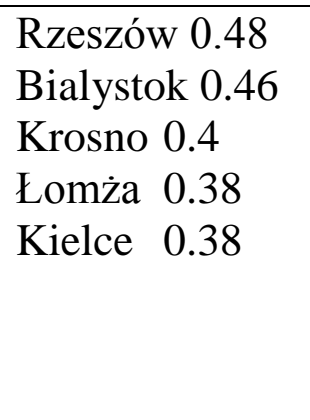 \\
\hline II & $\begin{array}{l}\text { Białystok } 0.48 \\
\text { Krosno } 0.44\end{array}$ & $\begin{array}{ll}\text { Biała } & \\
\text { Podlaska } & 0.38 \\
\text { Tarnobrzeg } & 0.38\end{array}$ & $\begin{array}{ll}\text { Lublin } & 0.48 \\
\text { Elbląg } & 0.48 \\
\text { Krosno } & 0.43\end{array}$ & $\begin{array}{l}\text { Lublin } 0.36 \\
\text { Tarnobrzeg } 0.36 \\
\text { Elbląg } 0.36 \\
\text { Olsztyn } \quad 0.36\end{array}$ \\
\hline III & $\begin{array}{ll}\text { Lomża } & 0.39 \\
\text { Suwałki } & 0.37 \\
\text { Biała } & \\
\text { Podlaska } & 0.36 \\
\end{array}$ & Suwałki & \begin{tabular}{ll}
\multicolumn{2}{l}{ Łomża 0.37} \\
Suwałki & 0.35 \\
Biała & \\
Podlaska & 0.34 \\
\end{tabular} & Suwałki \\
\hline IV & $\begin{array}{lr}\text { Zamość } & 0.34 \\
\text { Przemyśl } & 0.29 \\
\text { Chełm } & 0.29\end{array}$ & $\begin{array}{lr}\text { Zamość } & 0.33 \\
\text { Przemyśl } & 0.29 \\
\text { Chełm } & 0.28\end{array}$ & $\begin{array}{lr}\text { Zamość } & 0.32 \\
\text { Tarnobrzeg } & 0.31 \\
\text { Przemyśl } & 0.26 \\
\text { Chełm } & 0.25\end{array}$ & $\begin{array}{ll}\text { Biała } & \\
\text { Podlaska } & 0.32 \\
\text { Zamość } & 0.29 \\
\text { Przemyśl } & 0.27 \\
\text { Chełm } & 0.25\end{array}$ \\
\hline
\end{tabular}

Source: own study based on the GUS data 

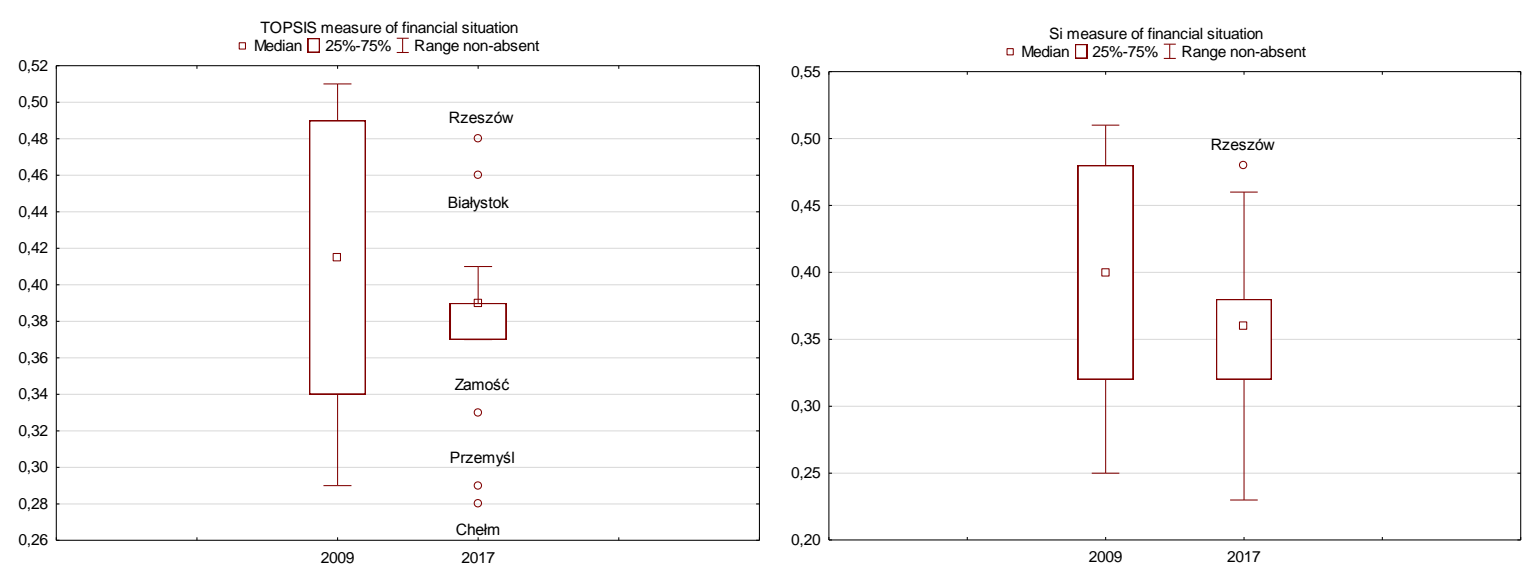

Figure 1. Dispersion of synthetic measures of the financial situation of cities with eastern poviat rights in Poland in 2009 and 2017

Source: own study based on the Central Statistical Office data

Figure 2 presents correlograms describing the year-to-year relations of synthetic measures of the financial situation of cities with poviat rights in Eastern Poland voivodships, for which the correlation coefficient is 0.778 (TOPSIS) and 0.754 (Si). Outlying units are Rzeszów, Olsztyn and Chełm. This indicates a similar reaction of cities with poviat rights to changes taking place in the economy and the spatial stability of the studied phenomenon.

In the theory of cumulative causation referring to the analysis of the interdependence of social, economic and institutional phenomena, Gunnar Myrdal has proved that every element interacting with another element affects its behavior, and at the same time it is modified by the reaction of that element (Stanny, Strzelczyk, 2018). The financial situation is strongly correlated with the measure of development potential with own revenues as well as with PIT and CIT, transfer revenues. The financial situation is also influenced by investment expenditure and expenditure on education and upbringing. 
Table 3

Differentiation of synthetic measures of the financial situation of cities with poviat rights in Eastern Poland voivodships in 2009 and 2017

\begin{tabular}{|l|c|c|c|c|}
\hline \multirow{2}{*}{} & \multicolumn{2}{|c|}{$\begin{array}{c}\text { TOPSIS financial } \\
\text { situation }\end{array}$} & \multicolumn{2}{c|}{ Si financial situation } \\
\cline { 2 - 5 } & $\mathbf{2 0 0 9}$ & $\mathbf{2 0 1 7}$ & $\mathbf{2 0 0 9}$ & $\mathbf{2 0 1 7}$ \\
\hline average & 0.41 & 0.38 & 0.40 & 0.36 \\
\hline standard deviation & 0.08 & 0.06 & 0.09 & 0.06 \\
\hline quarter (quartile) deviation & 0.42 & 0.39 & 0.40 & 0.36 \\
\hline classic coefficient of variation & 0.19 & 0.14 & 0.23 & 0.18 \\
\hline positional coefficient of variation & 1.00 & 0.99 & 1.01 & 0.98 \\
\hline min. & 0.29 & 0.28 & 0.25 & 0.23 \\
\hline max & 0.51 & 0.48 & 0.51 & 0.48 \\
\hline range & 0.22 & 0.20 & 0.26 & 0.24 \\
\hline quartile 1 & 0.34 & 0.38 & 0.32 & 0.33 \\
\hline quartile 2 & 0.42 & 0.39 & 0.40 & 0.36 \\
\hline quartile 3 & 0.49 & 0.39 & 0.48 & 0.38 \\
\hline quartile range & 0.14 & 0.02 & 0.16 & 0.05 \\
\hline skewness & -0.24 & -0.23 & -0.29 & -0.07 \\
\hline measure of concentration-kurtosis & 1.64. & 0.50 & -1.51 & 0.31 \\
\hline
\end{tabular}

Source: own study based on the Central Statistical Office data
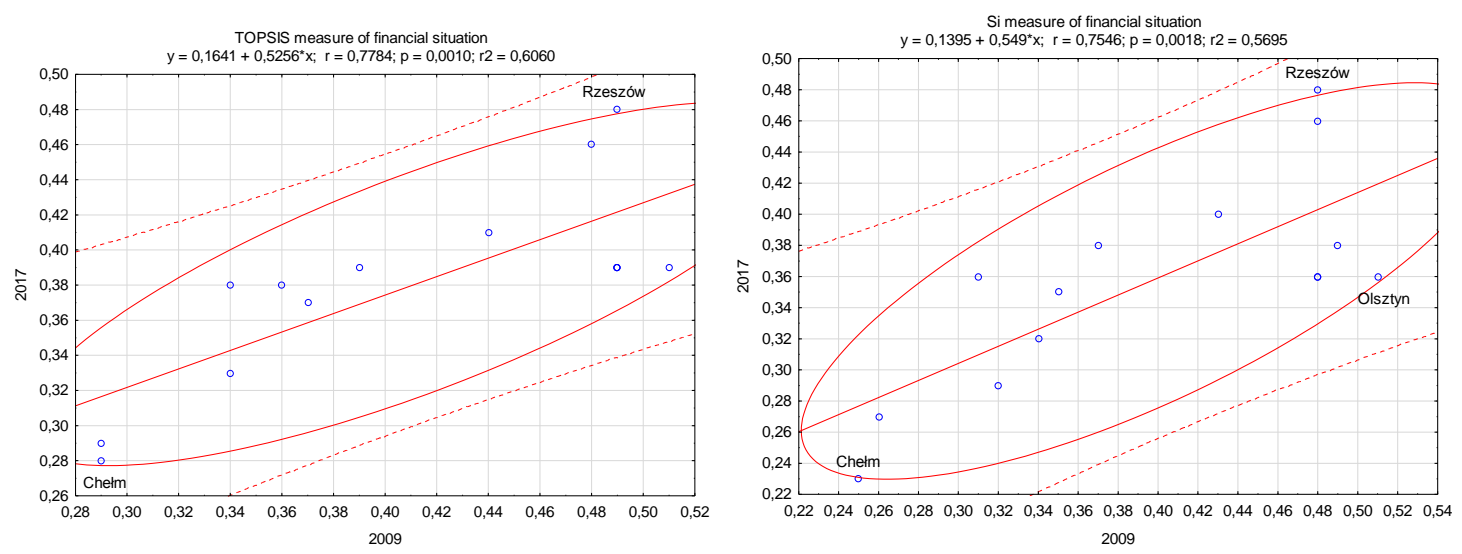

Figure 2. Scatter chart with an adjustment line synthetic measures of the financial situation of cities with poviat rights in Eastern Poland voivodships in 2009 compared to 2017

Source: own study based on the Central Statistical Office data

\section{Conclusions}

The methods used allowed to compare the financial situation of cities with poviat rights in Eastern Poland voivodships. The value of measures depended on the number and type of variables adopted for the study. They also made it possible to present a hierarchy and assess disproportions between individual 
cities with poviat rights in Eastern Poland voivodships. The design of the indicator used is not perfect, however, it ensures high comparability of the surveyed units, and the reliability and time range of the data used allow the formulation of cautious conclusions and generalizations. The proposed indicator can also be a starting point for further research taking into account a narrower or broader group of examined units [Pawlik, Dziekański, 2018]. By serving the region's local authorities to assess the effectiveness of development instruments used in the past, it confirms the need to introduce changes that can become the basis for the development of a knowledge-based economy.

In 2017, the financial standing measure (TOPSIS) ranged from 0.28 (Chełm) to 0.48 (Rzeszów), and in 2009 from 0.29 (Chełm, Przemyśl) to 0.51 (Olsztyn). The synthetic Si measure took values from 0.25 (Chełm) to 0.48 (Rzeszów) in 2017, and from 0.25 (Chełm) to 0.51 (Olsztyn) in 2009. Regardless of the method of determining the synthetic measure, the best financial situation in 2017 was in Rzeszów and Białystok, and the weakest in Chełm and Przemyśl.

The financial situation of cities with poviat rights of Eastern Poland voivodships was determined by their size and appropriate adjustment over time of income and expenditure. It was also influenced by the unit's development potential, own income as well as PIT and CIT income, transfer income and investment expenses as well as education and upbringing. The level of financial standing was also shaped by interactions with the level of unemployment, the number of employees or entities and natural persons conducting business activity.

The results of the analysis confirm the overall gradual improvement in the economic situation of Eastern Poland voivodships measured by variables describing the financial situation of cities with poviat rights. This is also demonstrated by a decrease in the level of unemployment and an increase in the number of registered business entities in the REGON register. It should also be pointed out that the values of the analyzed indicator for cities with poviat rights in Eastern Poland voivodships are low. The results also confirmed the significant importance of the poviat cities: Kielce, Rzeszów, Lublin, Białystok, Krosno, Olsztyn, Elbląg, Suwałki, Zamość, Biała Podlaska, Chełm, Łomża, Przemyśl and Tarnobrzeg as local centers of economic activity.

\section{References:}

1. Behzadian M. i inni (2012). A state-of the-art survey of TOPSIS applications. Expert Systems with Applications, 39(17), 13051-13069.

2. Berne R., (1996). Measuring and Reporting Financial Condition. Handbook of Public Administration, ed. J.L. Perry San Francisco: Jossey-Bass, https://dx.doi.org./10.1111/ j.1540-5850.2007.00872.x

3. Borodo A., (2007). Stownik finansów samorządowych, Toruń, Wyd. Dom Organizatora w Toruniu. 
4. Churski P., i inni (2013). Czynniki rozwoju obszarów wzrostu i obszarów stagnacji gospodarczej w Polsce, Poznań, Uniwersytet im. Adama Mickiewicza.

5. Dennis L., (2004). Determinants of Financial Condition: A Study of US Cities. Orlando, FL: University of Central Florida.

6. Dolewka Z., (2014). Bezpieczeństwo finansowe miast wojewódzkich. Nierówności Społeczne a Wzrost Gospodarczy. nr 40.

7. Douglas J.W., Gaddie R.K. (2002). State rainy day funds and fiscal crises: Rainy day funds and the 1990-1991 recession revisited, Public Budgeting \& Finance, t. 22, https:// doi: 10.1111/1540-5850.00063 (2002)

8. Dworakowska M., (2013). Zarzadzanie finansami miast na prawach powiatu. ZN Uniwersytetu Szczecińskiego, nr 786 Finanse, Rynki Finansowe, Ubezpieczenia. nr 64/2.

9. Dylewski M., Stasik B., (2012). Rola $i$ znaczenie miast na prawach powiatu $w$ realizacji zadań publicznych, W: Finanse $i$ ryzyko $w$ kształtowaniu rozwoju regionu, M. Dylewski (red.), ZN WSB w Poznaniu, nr 41.

10. Dziekański P., (2013). Wskaźnik syntetyczny $w$ procesie oceny gospodarki finansowej gmin wiejskich, Ekonomia. Economics, nr 3(24).

11. Dziekański P., (2014). Koncepcja wskaźnika syntetycznego do oceny sytuacji finansowej powiatów, Papers of Wrocław University of Economics, nr 329.

12. Dziekański P., (2018a). Lokalne dysproporcje infrastruktury miast makroregionu Polski Wschodniej $w$ kontekście budowy przewagi konkurencyjnej, Prace Naukowe Uniwersytetu Ekonomicznego we Wrocławiu, nr 502.

13. Dziekański P., (2018b). Analiza i ocena zróżnicowania regionalnego zmiennych infrastruktury i środowiska powiatów Polski Wschodniej, Humanities and Social Sciences, vol. XXIII, 25 (2).

14. Dziekański P., (2018c). Zróżnicowanie rozwoju powiatów Polski Wschodniej a problem samodzielności finansowej, Nierówności Społeczne a Wzrost Gospodarczy, nr 56 (4).

15. Dziekański P., Wyszkowski A., (2018). Ocena przestrzennego zróżnicowania sytuacji finansowej gmin województwa świętokrzyskiego $z$ wykorzystaniem miary syntetycznej. Optimum. Economic Studies NR 1 (91).

16. Dziekański P., Wiraszka P., (2018). The financial condition of eastern poland townships as a barrier to their development, Folia Pomer. Univ. Technol. Stetin., Oeconomica, 347(93)4.

17. Głowicka -Wołoszyn R., Wysocki F., (2014). Uwarunkowania społecznoekonomiczne samodzielności finansowej gmin województwa wielkopolskiego, Prace Naukowe Uniwersytetu Ekonomicznego we Wrocławiu, nr 346.

18. Hwang C.L., Yoon K., (1981). Multiple attribute decision making. Methods and applications, Springer, Berlin [for:] Bieniasz A., Gołaś Z., Łuczak A., (2013). Zróżnicowanie kondycji finansowej gospodarstw rolnych wyspecjalizowanych $w$ chowie owiec $i$ kóz $w$ krajach Unii Europejskiej, Roczniki Ekonomii Rolnictwa i Rozwoju Obszarów Wiejskich, T. 100, z. 1.

19. Kolenda M., (2003). Zamiana cechy na stymulantę, Prace Naukowe Akademii Ekonomicznej we Wrocławiu, Ekonometria, 11, nr 981, Zastosowania metod ilościowych.

20. Kotlińska J., (2012). Rozwój gospodarczy jednostek samorządu terytorialnego a zakres realizowanych przez nie zadań, Zeszyty Naukowe Wyższej Szkoły Bankowej w Poznaniu 2012, nr 42.

21. Kotlińska J., (2012). Rozwój gospodarczy jednostek samorzadu terytorialnego a zakres realizowanych przez nie zadań, Zeszyty Naukowe Wyższej Szkoły Bankowej w Poznaniu, nr 42.

22. Korenik S., (2011), Region ekonomiczny $w$ nowych realiach społecznogospodarczych, Warszawa, CeDeWu. 
23. Kozera A., (2016). Typologia miast na prawach powiatu wedtug poziomu zadtużenia w Polsce, $w$ latach 2007-2014. Optimum. Studia Ekonomiczne, NR 4(82).

24. Kukuła K., (2000). Metoda unitaryzacji zerowanej, Warszawa, PWN.

25. Lin W., Raman K.K., (1998). The housing value-relevance of governmental accounting information, Journal of Accounting and Public Policy, t. 17, $\mathrm{nr} 2$, https://dx.doi.org./10.1016/S0278-4254(98)10004-2

26. Malina A., (2004). Wielowymiarowa analiza przestrzennego zróżnicowania struktury gospo-darki Polski wedtug województw, Kraków, Wyd. Akademii Ekonomicznej w Krakowie.

27. Młodak A., (2006). Analiza taksonomiczna $w$ statystyce regionalnej, Difin, Warszawa.

28. Motek P., (2006). Gospodarka finansowa samorzadu terytorialnego $w$ województwie wielkopolskim. Poznań: Bogucki Wydawnictwo Naukowe.

29. Nowak E., (1990). Metody taksonomiczne w klasyfikacji obiektów społecznogospodarczych. Warszawa, PWE.

30. Ossowska L., Ziemińska A., (2010). Kondycja finansowa gmin wiejskich i miejskowiejskich województwa pomorskiego, Journal of Agribusiness and Rural Development 4(18).

31. Pawlik A., (2014), Dystans innowacyjny województw w 2016 roku, Wydawnictwo UJK, Kielce.

32. Pawlik A., (2018). Konkurencyjność miast na prawach powiatu województw wschodniej polski. Biuletyn KPZK PAN Komitet Przestrzennego Zagospodarowania Kraju PAN, Zeszyt 272.

33. Pietrzak M. B., (2016). The problem of the inclusion of spatial dependence within the TOPSIS Method. Montenegrin Journal of Economics, 12(3).

34. Satoła Ł., (2015). Kondycja finansowa gmin $w$ warunkach zmiennej koniunktury gospodarczej. Journal of Agribusiness and Rural Development, 1(35).

35. Sobczyk A., (2010). Rozwój lokalny - wybrane problemy finansowania. Zeszyty Naukowe SGGW, Ekonomika i Organizacja Gospodarki Żywnościowej, nr 81.

36. Standar A., (2017). Ocena kondycji finansowej gmin oraz jej wybranych uwarunkowań na przykładzie województwa wielkopolskiego przy wykorzystaniu metody TOPSIS. Wieś i Rolnictwo, 2(175), 69-92.

37. Stanny M., (2013). Przestrzenne zróżnicowanie rozwoju obszarów wiejskich $w$ Polsce, Warszawa, IRWiR PAN.

38. Stanny M., Strzelczyk W., (2015). Zróżnicowanie przestrzenne sytuacji dochodowej gmin a rozwój społeczno-gospodarczy obszarów wiejskich $w$ Polsce, Stowarzyszenie Ekonomistów Rolnictwa i Agrobiznesu Roczniki Naukowe, tom XVII, zeszyt 4.

39. Stanny M., Strzelczyk W., (2018). Kondycja finansowa samorzadów lokalnych a rozwój społeczno-gospodarczy obszarów wiejskich; Ujęcie przestrzenne, Warszawa, Wyd. Instytut Rozwoju Wsi i Rolnictwa PAN oraz Wyd. Naukowe Scholar Spółka z o.o.

40. Wang X.. i in. (2007). Measuring financial condition: a study of U.S. states, Public Budgeting \& Finance, Vol. 27, No. 2.

41. Wójcik-Leń J., i inni (2019). Studies regarding correct selection of statistical methods for the needs of increasing the efficiency of identification of land for consolidation-A case study in Poland. Land Use Policy, 87.

42. Wysocki F., (1996). Metody statystycznej analizy wielowymiarowej $w$ rozpoznawaniu typów struktury przestrzennej rolnictwa, Poznań, Roczniki AR w Poznaniu, seria: Rozprawy Naukowe, z. 266.

43. Wysocki F., Lira J., (2005). Statystyka opisowa, Poznań, Wyd. AR. 
44. Wyszkowska D., Wyszkowski A., (2015). Samodzielność dochodowa samorzadu terytorialnego w Polsce. Studia i Materiały. Miscellanea Oeconomicae, nr 2.

45. Zalewski W., (2012). Zastosowanie metody TOPSIS do oceny kondycji finansowej spółek dystrybucyjnych energii elektrycznej, Ekonomia i Zarządzanie, 4.

46. Zeliaś A., Malina A., (1997). O budowie taksonomicznej miary jakości życia. Syntetyczna miara rozwoju jest narzędziem statystycznej analizy porównawczej, Taksonomia z. 4. 